\title{
Genç Yetişkinlerin Televizyondaki Dini Programlara Yönelik Tutumları ve Güven Düzeylerinin Belirlenmesi: Ampirik Bir Araştırma
}

\author{
İsmailcan Doğan (Dr. Öğr. Üyesi) \\ Erciyes Üniversitesi İletişim Fakültesi \\ ismailcandogan@erciyes.edu.tr \\ Başvuru Tarihi: 25.09.2020 \\ Yayına Kabul Tarihi: 12.01.2021 \\ Yayınlanma Tarihi: 29.01.2021 \\ https://doi.org/10.17680/erciyesiletisim.800096 \\ Öz
}

Televizyon, birçok işlevi bulunan önemli bir kitle iletişim aracıdır. Bu işlevlerden geniş kitlelere ulaşabilme, bilgi edinmede bir kaynak rolü üstlenme, içeriğinde yer alan kanal ve programların çeşitliliği ve buna benzer birçok özelliği televizyonu hayatın vazgeçilmez bir parçası haline getirmiştir. Televizyon, kitle iletişim araçları içerisinde dini anlamda en sık başvurulan kaynaklardan birisidir. Özellikle kutsal gün ve gecelerde öne çıkan dini içerikli televizyon programlarında, dini anlamda farklı tartışmalara yer verilmekte, böylece dini bilgi toplum içerisinde yayılmaktadır. Ancak televizyondaki dini programların sayısının her geçen gün artması, programlardaki uzmanların dini anlamda yeterlilik düzeyleri, dini bilgilerin manipüle edilmesi gibi değișkenler, televizyondaki dini programlara yönelik izleyicilerin farklı tutumlar içerisine girmesine ve dini programların güvenilirliklerinin izleyiciler tarafından sorgulanmasına neden olmaktadır. Bu sorgulamayı yapan ve dini içeriğe sahip programları izleyen kitleler ele alındığında karşımıza farklı demografik gruplar çıkabilmektedir. Zira dini içerikli programlar tıpkı diğer programlar gibi hem kendi içerisinde hem de izleyici kitlesi anlamında farklılıklar arz etmektedir. Bu anlamda dini programların izleyici kitlesi arasında yer alan genç yetişkinler konunun önemli bir yönünü oluşturmaktadır. Bu programlara yönelik olarak genç yetişkinlerin bakış açlları, güven düzeyleri ve tutumları şüphesiz ortaya çıkarılması gereken önemli bir konudur. Buradan hareketle bu çalışma ile literatürde yapılan tartışmalara ampirik verilerle katkı sunmak amaçlanmaktadır. Araştırma verileri anket yöntemiyle toplanmıştır. Çalışmanın örneklemi Kayseri ili merkezinden tesadüfi örneklem yöntemi ile belirlenmiştir. Hazırlanan anket formu toplamda 303 kişiye uygulanmıştır. Bulgular, genç yetişkinlerde kadınların erkeklere oranla televizyondaki dini programlara güven düzeylerinin daha düşük olduğunu göstermektedir. Ayrıca gençler bu programlarda uzman olmayan kişilere yer verilmemesi gerektiğini düşünmektedirler.

Anahtar Kelimeler: Medya, Televizyon, Din, Medya ve Din, Televizyon Programları. 


\title{
Determining Young Adults' Attitudes and Confidence Levels towards Religious Programs on Television: An Empirical Study
}

\author{
İsmailcan Doğan (Asst. Prof. Dr.) \\ iD Erciyes University Faculty of Communication
}

ismailcandogan@erciyes.edu.tr

Date Received: 25.09.2020

Date Accepted: 12.01 .2021

Date Published: 29.01.2021

https://doi.org/10.17680/erciyesiletisim.800096

\begin{abstract}
Television is an important mass media tool with many functions. From these functions, the ability to reach a wide audience, take on the role of a source in obtaining information, the variety of channels and programs contained in its content, and many similar features have made television an indispensable part of life. Television is one of the most frequently referenced sources in the mass media in the religious sense. Especially on Holy Days and nights, television programs with religious content feature different discussions in the religious sense, so that religious information is spread within the society. But the increasing number of religious programs on television every day, the level of competence of experts in the programs in the religious sense, variables such as manipulation of religious Information, cause viewers to take different attitudes towards religious programs on television and question the reliability of religious programs by viewers. Considering the masses who conduct this interrogation and watch programs with religious content, we may encounter different demographic groups. Because religious content programs, like other programs, have differences both within themselves and in terms of the audience. In this sense, young adults who are among the audience of religious programs constitute an important aspect of the subject. Young adults' perspectives, confidence levels, and attitudes towards these programs are undoubtedly an important issue that needs to be raised. Based on this, it is aimed to contribute to the discussions in the literature with empirical data. Research data was collected by survey method. The sample of the study was determined by random sampling method from the center of Kayseri province. The prepared questionnaire was applied to 303 people in total. The findings show that women in adults have lower levels of trust in religious programs on television than men. Besides, young people believe that non-experts should not be included in these programs.
\end{abstract}

Keywords: Media, Television, Religion, Media and Religion, Television Programs. 


\section{Giriş}

Sanayi devrimiyle birlikte birçok alanda olduğu gibi iletişim alanında da baş döndürücü gelişmeler yașanmıștır. Bu gelişmelerden birisi hiç şüphesiz kitle iletişim alanındaki gelişmelerdir. İnsanların yaşam tarzlarını etkileyen kitle iletişim araçları, bu anlamda önemli bir yere sahiptir. Bu araçlardan birisi olan televizyon da bu bağlamda toplum ve bireyler üzerindeki değişimin en önemli aktörlerinden birisi olmuştur. 20. yüzyılda başlayan televizyon yayıncılığı, görüntü ve sesin aynı anda ve canlı olarak iletilmesi özelliği ile diğer kitle iletişim araçlarından ayrılmış ve öne çıkmıștır.

Diğer taraftan iletişim bilimciler televizyon ve medya ile ilgili birçok araștırma yapmış televizyonun kitleler üzerinde nasıl bir etki bıraktığını anlamaya çalışmışlardır. Bilindiği gibi geçmişten bu yana medya ile ilgili yapılan araştırmaların en önemli odak noktalarından birisi etki araştırmalarıdır. İzleyicinin, aktif hale geldiğini savunan kullanımlar ve doyumlar yaklaşımı "medya insanlara ne yapıyor?" sorusundan sıyrılarak "insanlar medya ile ne yapıyor?" sorusuyla konuya farklı bir açıdan yaklaşmıştır. Kullanımlar ve doyumlar yaklaşımı ile izleyicinin aktif hale geçmesiyle bireyler; medyanın etkisine direnç gösterebilen ve kendi arzularına yönelik olarak tercihte bulunan kişiler olarak kabul edilmiştir. Bu yaklaşım aynı zamanda bireylerin sosyal ve bireysel bazı ihtiyaçları bulunduğunu bize açıklamaktadır. Bireyler, ihtiyaçlarını karşılama olanağı bulamadıklarında ise ihtiyaçlarını giderecek işlevi olan araçlara yönelmektedirler. Bireylerin farklı gereksinimleri ile doyuma ulaşma çabası iletişim araçlarının farklı şekillerde kullanımıyla sonuçlanmıştır (Rosengren, 1974, s. 270). Blumler ve Katz, medyanın doyuma ulaştırdığı gereksinimlerin toplumsal kökenleri bulunduğunu vurgulamışlardır (Fiske, 2003, s. 199-200).

Bununla beraber televizyon, toplumun üzerinde etkili bir kitle iletişim aracıdır. Toplumun kültür ve yaşamını etki altına almaktadır. Bunun nedeni ise televizyonun hem göze hem kulağa hitap etmesi hem de bir yaşam tarzı ve kültür inşa eden bir araç olmasındandır. Bu bakımdan dilden sanata, siyasetten kültürel değerlere, dinden ideolojilere kadar birçok kavram televizyon dünyasında kendine yer bulmaktadır (Bilis, 2017, s. 196).

Bilindiği gibi televizyonda insanların dikkatini çekecek ve onları doyuma ulaştıracak birçok program türü vardır. Ekonomi programlarından, spor programlarına, eğlence programlarından, kültür sanat programlarına izleyicinin izleyebileceği birçok seçenek mevcuttur. Bu programlardan birisi de dini içerikli programlardır. Postman (2010, s. 132) televizyonda yayınlanan dini programların basitleștirilerek bir eğlence olarak insanlara sunulduğunu belirtmektedir. Ona göre normalde olması gereken dinin tarihsel, derinlikli, kutsal ve insani etkinlik olma durumu televizyondaki dini programlarda silinmiştir. Dini programlarda başlıca rol vaize verilmiş ve din aslında ikinci plana atılmıştır.

Bilis'e (2017, s. 197) göre bu eleștiriler, dinin ve dinsel olanın televizyon alanına taşınması sırasında bazı sıkıntılar veya sorunlar olduğuna da işaret etmektedir. $\mathrm{Bu}$ olasılığa karşın dini programlar yapılmaya devam edilmektedir ve bu programlar; dini bilginin yayılmasında, dini içerikli sorulara cevap verilmesinde, dini dünya görüşünün ve değer yargılarının yansıtılmasında dini mabetlerin de ötesinde bir gücü temsil etmeye başlamıștır.

Dinin televizyonda yayınlanması ve dini bilginin televizyondan alınması gibi konularda gelen eleştiriler ne düzeyde olursa olsun bu tür programların milyonlarca insanı ekran başına topladığı yadsınamaz bir gerçektir (Postman, 2010, s. 139). Televizyonun 
birçok özelliği bünyesinde barındırması hem görüntüyü hem sesi aynı anda hızlı bir biçimde kitlelere ulaştırabilmesi geçmişten bugüne televizyonun izleyici tarafından bu denli tercih edilmesinde önde gelen sebeplerden olmuştur. $\mathrm{Bu}$ çalışma, genç izleyicilerin televizyondaki dini programlara bakış açılarını ve izleme alışkanlıklarını, neden izlediklerini, bu programlara güven düzeylerini ve tutumlarını ortaya çıkarmayı amaçlamaktadır. Bu bağlamda çalışmamız literatür ve araştırma bölümlerinden oluşmaktadır. Literatür bölümünde öncelikle televizyon ve din arasındaki ilişkiye kısaca değinilmiştir. Araştırma bölümünde ise konuyla ilgili bir alan araştırması ve sonuçlarına yer verilmiştir.

\section{Televizyon ve Din}

Din, bireyin doğumundan ölümüne kadar toplumsal hayatın içerisinde bulunan en önemli dinamiklerden birisidir. Toplumdaki bireylerin yaşam tarzlarını etkileyen bir olgu olarak toplum için oldukça hassas ve önemli bir konudur (Turan, 2005, s. 35).

Bilindiği gibi din ile ilgili bilgi edinme aile, ibadethaneler, vaazlar gibi geleneksel yollarla olmaktadır. Bununla birlikte kitle iletişim teknolojilerindeki gelişmelerle birlikte, kitle iletişim araçları da günümüzde dini bilgi edinmede önemli bir konuma gelmiştir. $\mathrm{Bu}$ süreçte televizyonun iki ana fonksiyonla bu görevi yerine getirdiği söylenebilir. Birincisi medyanın dini bilgileri aktarımı yoluyladır. Medya ile geniş kitlelere dini bilgiyi anlatma ve benimsetme faaliyetleri yapılabilmektedir. İkinci fonksiyon ise "rol model" olarak sunulan karakterlerle ilgilidir. Televizyondaki dini karakter ve figürler, dini programlar aracılığ ile bireyin taklit etmeye çalıștığı ve dini tutum ve davranışlarını buna göre şekillendirdiği birer rol model olarak görülebilmektedir. Bu rol modellerin özellikle gençler üzerinde daha etkili olduğu söylenebilir. Bu yönüyle kitle iletişim araçlarının dini bilgi edinmede geleneksel yöntemlerin yanında hem iyi bir alternatif olduğu söylenebilirken hem de tartışılan yönlerinin olduğu ifade edilebilir (Arslan, 2016, s. 10). Bu tartışmanın içerisinde yer alan ve dini bilgi edinmede önemli bir işleve sahip olan kitle iletişim araçlarından birisi de hiç şüphesiz televizyondur. Genel olarak bakıldığında televizyonun izleyici üzerinde üç işlevi vardır. Bunlardan birincisi eğitim ve kültür düzeyinin yükseltilmesi, ikincisi bilgi edinme, üçüncüsü ise eğlenme ve sosyalleşme olarak ele alınabilir (Gelici, 2007 , s. 11). Televizyondaki dini programların öncelikli amacının izleyicileri dini anlamda bilgilendirmek olarak düşünülse de bu programların aynı zamanda izleyicilerin bir günah çıkarma ritüeline döndüğünden de bahsedilebilir (Tanrıverdi, 2016, s. 14).

Televizyonu dini bilgi edinme açısından ele aldığımızda birçok avantajı ve dezavantajı olduğu ifade edilebilir. Avantajlarından birisi öncelikle zengin içeriğe sahip olan televizyonda, izleyicilerin tercih yapabilmesine imkân sağlayan birçok dini programın bulunmasıdır. Bununla birlikte sadece televizyonun değil, genel olarak kitle iletişim araçlarının bu yönü, dini açıdan beslenmek ve bilgi edinmek isteyen izleyicilere bir avantaj sunmaktadır. Öte yandan bir diğer avantaj ise televizyondaki programların dini bilgiyi izleyicilere basitleştirerek sunmasıdır. Bu sayede daha anlaşılabilir olan bilgiler, izleyiciler üzerinde daha etkili olmaktadır. Televizyonun dezavantajları ise yukarıda değinilen çeşitliliğin beraberinde otorite sorununu getirmesi ve bunun yanında dinin bir meta haline getirilerek kitlelere sunulması olarak ele alınabilir (Arslan, 2016, s. 12-13). Bu bağlamda televizyon ve din arasındaki ilişki tartışılmaya devam edilen bir konu olarak karşımıza çıkmaktadır.

Televizyon ve din arasındaki ilişkinin önemli bir başka boyutu Gülerarslan'a (2010, s. 225) göre her iki kavramın da farklı referanslara sahip olmasıdır. Din konusu öteki dünya 
ekseninde uhrevi bir iklime sahipken, televizyon ise tam tersi dünyevi bir araç olarak karşımıza çıkmaktadır. Bu nedenle din konusu ne kadar ciddi bir biçimde ele alınırsa alınsın, televizyon aracının yapısı itibariyle tam anlamıyla dini olarak duyumsama gerçekleşmemektedir. Postman (2010, s. 132-138) ise televizyonun her şeyi olduğu gibi dini de basit bir biçime indirgediğini ve bir eğlence ürünü olarak izleyiciye sunduğundan bahsetmektedir. $\mathrm{Bu}$ durumun da dini ası anlamından koparıp, değersiz bir hale getirdiğini söylemektedir. Ayrıca televizyonda vaaz veren kişilerin ön plana çıkarılarak adeta putlaştırıldığından bahsetmektedir. Bununla birlikte televizyonun dini programları magazinleștirmesi, asıl verilmek istenen mesajın bağlamından koparması veya eleştirel bir yolla akıl yürütmeye uygun olmayan programlara dönüştürmesi, dini bağlamda ele alındığında eleştirilen diğer noktalardır (Çelikkaya, 2010, s. 58). Ancak bu yalnızca televizyon için değil kitle iletişim araçlarının neredeyse tamamı için geçerli olabilecek bir husus olarak ifade edilebilir. Medyatikleşme kavramıla ifade edilebilecek bu durum medyatik kurgunun, dini anlamları özgün bağlamlarından ayırarak farklı yollarla yeniden üretebilme kapasitesine gönderme yapar (Eken, 2020, s. 34).

Televizyondaki dini programlara yönelik literatürdeki bu eleștirilere rağmen televizyondaki dini içerikler her geçen gün çeşitlenmeye ve artmaya devam etmektedir. Televizyondaki dini içerikli programlar aracılığı ile dini bilgi yayılmakta, sorular cevap bulmakta, dini görüşler yayılmakta ve yansıtılmaktadır. Televizyondaki dini içerikli programların sayısının artması ve içeriğin çeşitlenmesi geleneksel dini bilgi edinmede kullanılan aile, ibadethane, okul vb. ile birlikte televizyonun da etkisini güçlendirmiştir (Bilis, 2017, s. 197).

\section{Literatür}

Literatürde öncelikle genel olarak medya konusunu ele aldığımızda, izleyicilerle ilgili sayısız görgül araştırma yapıldığını görmekteyiz. Bu araştırmaların bir kısmı medyada sergilenen şiddetin etkileri üzerinde yoğunlaşmıştır. Psikologlar laboratuvar deneyleri yapmış, toplum bilimciler geniş ölçekli alan araştırmaları gerçekleştirmişlerdir (Fiske, 2003, s. 194). Bununla beraber medyanın ve din algısındaki rolü ile ilgili çalışmalar da (Güneş, 2018) yapılmıştır. Diğer yandan kitle iletişim aracı olarak televizyon ve din eksenli çalışmaların da literatürde farklı açılardan tartışıldığı gözlemlenmiştir. Konu yerli ve yabancı olarak iki açıdan ele alınabilir.

Öncelikle yerli literatürde yapılan araştırmalara baktı̆̆ımızda akademik çalışmalarla beraber, Diyanet İşleri Başkanlığı tarafından da 2014 yılında geniş kapsamlı bir araștırma yapıldığı görülmektedir. Konunun önemi bakımından araştırma sonuçları dikkat çekici veriler sunmaktadır. Buna göre dini bilgi edinme kaynağı olarak medyadan faydalandığını söyleyen katılımcıların oranı \%24,6 olarak ortaya çıkmıştır. Bu sonuç katılımcıların neredeyse dörtte birinin dini bilgileri kitle iletişim araçlarından öğrendiğini göstermektedir. Yine aynı araştırma sonuçlarına göre televizyon ve radyoda dini içerikli programları takip ettiklerini söyleyenlerin oranı \%48,8 olarak ortaya çıkmıştır. Araştırmanın dikkat çeken sonuçlarından birisi de eğitim seviyesi ile medyadaki dini programları takip edenlerin arasındaki ilișkidir. Buna göre eğitim seviyesi yükseldikçe medyadan dini bilgi edinme oranında bir düşüş olduğu sonucu ortaya çıkmıştır (Diyanet İşleri Başkanlığı, 2014).

Gülerarslan (2010) konuyla ilgili yaptığı bir değerlendirmede, televizyonu sekülerliğin en önemli unsurlarından birisi olduğunu vurgulamıştır. Televizyonun her tür dinamiği olduğu gibi dini de kendi karakterine uygun bir formda izleyiciye sunduğu ve yeri 
geldiğinde toplumun en mahrem konularına bile değindiğini belirtmiştir. Diğer taraftan; dinin kitle iletişim araçları sayesinde daha görünür olduğu ve bunun sonucunda da dinin popüler bir özellik kazandığını savunan görüşler de literatürde yer almaktadır (Arslan, 2016).

Yerli literatürde televizyon ve din konusunda yapılmış ampirik araştırmalara da rastlanılmıştır. Tanrıverdi'nin (2016), televizyondaki dini programların gençlerin dini tutum ve davranışları üzerindeki etkilerinin incelendiği araştırmaya göre, dini programların üniversite çağındaki gençlerin dini tutum ve davranışlarında değişiklik oluşturduğu sonucuna ulaşılmıştır. Araştırma sonuçlarına göre araştırmaya katılan üniversite öğrencilerinin \%27,27'si dini bilgi edinmek için televizyondaki dini programları takip ettiğini belirtmişlerdir. Aynı araştırma sonuçlarına göre dikkat çeken bir diğer husus televizyondaki dini programlara güven ile ilgilidir. Buna göre katılımcıların büyük çoğunluğu $(\% 70,2)$ çeşitli düzeylerde söz konusu programlara güvenmediklerini ifade etmişlerdir. Benzer bir başka araştırma ise konuya dini içerikli diziler özelinde yaklaşmıștır. Yetişkinlerin yaygın din eğitiminde televizyonun yeri ve fonksiyonları bağlamında yapılan bir başka araştırmanın sonucuna göre ise söz konusu dini temalı dizilerden en fazla etkilenen cinsiyet grubunun kadınlar olduğu görülmektedir. Yine bu araştırmanın bir başka ilgi çekici bulgusuna göre söz konusu dizileri izlemeyenlerin bile $(\% 65,8)$ bu dizileri faydalı bulmalarıdır (Furay, 2008). Konuyla ilgili bir başka araștırma ise Yenen (2005) tarafından yapılmıștır. Televizyonlarda yayınlanan dini programların izlerkitlenin dini tutum ve davranışları üzerine odaklanan bu araştırma sonuçları ise izleyicilerin dini programları dini bilgi edinme amacıyla seyrettikleri ancak dini tutum ve davranış değişikliği noktasında, dini programlardan edindikleri bilgilere temkinli yaklaştıklarını ortaya çıkarmıştır.

Konuya yetişkin izleyiciler perspektifinden yaklaşılan bir başka araştırmada, televizyonun dini yaşam üzerinde belirli bir etkisi olduğu, televizyonun kamuoyu oluşturma gücünden dolayı televizyonun dine bakışının, toplumun dine bakışı haline geldiği sonucuna ulaşılmıştır. Aynı araştırmanın bir başka sonucu, yetişkinlerin dini programlara ilgisinin düşük olduğunu göstermektedir (Turan, 2005).

Yabancı literatür incelendiğinde de benzer şekilde televizyondaki dini içeriklere yönelik araştırmalar yapıldığı görülmektedir (Gerbner, 2017; Kazi, 2018; Tolz, 2017; Engstrom ve Valenzano, 2014; Frederick, 2015).

Televizyon ve din arasındaki ilişkiyi kültürel bağlamda araştırdığı bir araștırmada Martin (2007) televizyonun kişisel maneviyatın inşa edilmesinde önemli bir rolü olduğu sonucuna ulaşmıștır. Söz konusu araştırmada 30 katılımcıyla yapılan derinlemesine görüşme sonuçlarına göre, katılımcılar televizyonu dini bir kaynak olarak maneviyatlarını inşa etmede önemli bir araç olarak gördüklerini belirtmişlerdir. Yabancı literatürde yapılan bir başka araştırma televizyondaki dini programları izleme ve kiliseye gitme arasındaki ilişkiyi ele almıştır. Dufek (1992) tarafından yapılan araştırmada ortaya çıkan sonuçlar, dini içerikli televizyon programlarını izlemenin kiliselere gitme oranını arttırdığını göstermiştir. Thomas ve Mitchell'in (2005) Hristiyanlar üzerinde yaptığı bir başka araştırma, televizyondaki dini içerikli programların Hristiyanların diğer dinlerle olan diyalogları bağlamında bir etkisi olmadığı sonucunu ortaya çıkarmıştır. Ancak aynı araștırmada, katılımcıların kendi dini kimliklerini söz konusu programların aracılığı ile pekiştirdikleri sonucu dikkat çekmektedir. 
Literatürde televizyon ve din arasındaki ilişkinin açıklanmaya çalışıldığg araştırmalar yukarıda da görüldügü gibi dini bilgi edinme ve insanların tutum ve davranışlara etkisi ekseninde ele alınmıştır. Bu noktada televizyondaki dini programlara izleyicilerin ne derece güvendikleri ve bu programlara yönelik tutumları, söz konusu çalışmaların yanında konunun önemli bir boyutunu oluşturmaktadır. Diğer taraftan günümüzde artık hemen hemen her eve giren ve büyük kitlelere hitap etme yeteneği olan televizyon izleyicilerinin önemli bir kısmını gençler oluşturmaktadır. Yukarıda da görüldüğü üzere televizyon ve din ile ilgili çalışmalar toplumun değişik kesimleri üzerinde yapılmıştır. $\mathrm{Bu}$ bağlamda gençlerin geleneksel bilgi edinme araçlarının yanı sıra televizyonu da bir dini bilgi edinme aracı olarak kullanımı, televizyondaki dini programlara bakışlarını ve güven düzeylerini ortaya koymak, araştırılması gereken bir konu olarak ele alınabilir. Çalışmamız bu anlamda yukarıdaki çalışmalardan ayrılmaktadır.

\section{Araştırmanın Yöntemi}

Televizyondaki dini içerikli programlara yönelik bireylerin tutumlarının ve güven düzeylerinin genç yetişkinler bağlamında incelendiği bu araştırma betimsel bir karaktere sahiptir. Bu bölümde araştırmanın amacı ve önemi, veri toplama aracı, evren ve örneklem ile araştırmanın sınırlılıkları açıklanmıştır.

\subsection{Araştırmanın Amacı ve Önemi}

Araştırmamız gençlerin, önemli kitle iletişim araçlarından olan televizyondaki dini programlara güven düzeylerine odaklanarak konu ile ilgili olarak literatürde yapılan tartışmalara ampirik verilerle katkı sunmayı amaçlamaktadır. Bu kapsamda araştırmamızın temel soruları şu şekildedir;

Araştırma sorusu 1: Gençlerin medya araçlarını kullanma sıklıkları ne düzeydedir?

Araştırma sorusu 2: Gençlerin televizyondaki dini programları izleme sıklıkları nedir?

Araştırma sorusu 3: Gençlerin televizyonu takip etme amaçları nedir?

Araştırma sorusu 4: Gençlerin televizyondaki dini programlara güvenleri ne düzeydedir? Araştırma sorusu 5: Gençlerin televizyondaki dini programlara bakış açıları nedir?

Yapılan literatür taraması sonucunda konuyla ilgili yerli literatürde farklı perspektiften çalışmalar yer aldığı görülmektedir. Tartışmalar genellikle dini bilgi edinme, sekülerlik ve televizyondaki dini programların izleyici üzerindeki etkileri bağlamında ele alınmaktadır. Çalışmamız ise konuya genç yetişkinlerin dini programlara yönelik tutumları ve güven düzeyleri açısından yaklaşmaktadır. Araştırmamızda veriler anket yöntemiyle elde edilmiştir. Özellikle yerli literatür incelendiğinde saha çalışmalarının yetersiz olması ve çalışmamızın bir alan araştırması olması, çalışmamızın önemini arttırmaktadır.

\subsection{Veri Toplama Aracı}

Araştırmamız kapsamında yaptığımız alan araştırması için bir anket formu oluşturulmuştur. Anket formu Aralık 2019'da Kayseri ili merkez ilçelerinde yüz yüze gerçekleştirilirmiştir. Oluşturulan soru formu üç bölümden oluşmaktadır. İlk bölümde kitle iletişim araçlarını kullanma sıklıkları ile ilgili sorular, ikinci bölümde medyadaki dini programlarla ilgili tutum ve davranışların ortaya konulması amacıyla sorulan sorular ve son bölümde ise katılımcıların sosyo-demografik özelliklerini belirlemeye yönelik sorular sorulmuştur. Araştırmada kullanılan sorularda 5'li likert ölçek tipi kullanılmıştır. Katılımcıların kitle iletişim araçlarını kullanma sıklık derecelerini ortaya koymak için 1: Hiç, 2: Nadir, 3: Bazen, 4: Sık sık, 5: Sürekli seçenekli sorular sorulmuştur. Daha sonra ise katılımcıların televizyondaki dini programlara yönelik tutumlarını ve güven düzeylerini 
ortaya koymak için sorulan soru grubunda, katılımcılardan 1: Kesinlikle katılmıyorum, 2: Katılmıyorum, 3: Fikrim yok, 4: Katılıyorum, 5: Kesinlikle katılıyorum seçeneklerinden birisini işaretlemesi istenmiștir. Son olarak ise katılımcıların sosyo-demografik özellikleri ile ilgili sorular yöneltilmiştir.

\subsection{Evren ve Örneklem}

Televizyonda ve dini programlara güven düzeyi sınırlandırılarak 18- 30 yaş arası gençlere odaklanılmıştır. Çalışmanın örneklemi Kayseri ili merkezinde yaşayan 18-30 yaş arası genç yetişkinler arasından tesadüfi olarak seçilmiştir. Kayseri nüfusu göz önüne alındığında, yapılan ön inceleme sonucunda, 303 anket analiz için uygun görülmüştür. Verilerin analizi SPSS 22 istatistik paket programında yapılmıştır. Araştırmamızda frekans, ortalama, kikare, ortanca, en düşük en yüksek değer ve t-testi analizleri kullanılmış ve ortaya çıkan sonuçlar tablo haline getirilerek yorumlanmıştır.

\subsection{Araştırmanın Sınırlılıkları}

Araştırmamız genç yetişkinler üzerinde yapılan bir araştırmadır. Bu bağlamda 1830 yaş aralığındaki bireyler araştırmamızın temel sınırlılığını oluşturmaktadır. Ayrıca araştırmamız evrenin tamamına ulaşılması, maliyet ve zaman açısından zor olduğundan dolayı, Kayseri ili merkez ilçelerinde yapılmıștır. Diğer taraftan araştırmamızın veri toplama araçlarından olan anket yöntemi ile sınırlıdır.

\subsection{Etik Kurul İzni}

Erciyes Üniversitesi Sosyal ve Beşeri Bilimler Etik Kurulu 28/08/2020 tarih ve 136 başvuru no'lu kararı çerçevesinde çalışma etik açıdan bir sakınca içermemektedir.

\section{Bulgular}

Așağıda öncelikle araştırmaya katılan katılımcıların sosyo-demografik özelliklerine ve daha sonra frekans, $t$ testi ve çapraz tablolara yer verilmiştir.

Araștırmaya katılan deneklerin bazı sosyo-demografik özellikleri Tablo 1'de görülmektedir. Buna göre katılımcıların \%58,4'ü kadın, \%41,6'sı ise erkeklerden oluşmaktadır. Yaş dağılımları incelendiğinde katılımcıların \%46,53'ü 18-21 yaş, \%37,95'i 22-25 yaş \%15,51'i ise 26-30 yaş aralığındadır. Öğrenim durumları incelendiğinde ilk ve ortaokul mezunu $\% 3$, lise mezunu $\% 44,6$, lisans mezunu \%50,2 lisansüstü ise \%2,3 olarak ortaya çıkmıştır. Katılımcıların ekonomik durumları ise \%5,3 1000 TL'den az, $\% 32,3$ 1001-2500 TL, \%42,2 2501-4500 TL, \%13,5 4501-6000 TL ve \%6,6 ise $6001 \mathrm{TL}$ ve üstü gelir düzeyine sahiptir.

Tablo 1. Katılımcıların Sosyo-Demografik Yapısı

\begin{tabular}{|c|c|c|c|}
\hline & & Frekans & Yüzde \\
\hline \multirow{3}{*}{ Cinsiyet } & Kadın & 177 & 58,4 \\
\hline & Erkek & 126 & 41,6 \\
\hline & Toplam & 303 & 100,0 \\
\hline \multirow{4}{*}{ Yaş Dağılımı } & 18-21 yaş & 141 & 46,53 \\
\hline & 22-25 yaş & 115 & 37,95 \\
\hline & $26-30$ yaş & 47 & 15,51 \\
\hline & Toplam & 303 & 100,0 \\
\hline
\end{tabular}




\begin{tabular}{|c|c|c|c|}
\hline & & Frekans & Yüzde \\
\hline \multirow{6}{*}{ Öğrenim Durumu } & İlkokul & 7 & 2,3 \\
\hline & Ortaokul & 2 & 7 \\
\hline & Lise & 135 & 44,6 \\
\hline & Lisans & 152 & 50,2 \\
\hline & Lisansüstü & 7 & 2,3 \\
\hline & Toplam & 303 & 100,0 \\
\hline \multirow{6}{*}{ Ekonomik Durum } & 1000 TL'den az & 16 & 5,3 \\
\hline & $1001-2500 \mathrm{TL}$ & 98 & 32,3 \\
\hline & $2501-4500 \mathrm{TL}$ & 128 & 42,2 \\
\hline & 4501-6000 TL & 41 & 13,5 \\
\hline & 6001 TL ve üstü & 20 & 6,6 \\
\hline & Toplam & 303 & 100,0 \\
\hline \multirow{3}{*}{ Medeni Durum } & Evli & 21 & 6,9 \\
\hline & Bekar & 282 & 93,1 \\
\hline & Toplam & 303 & 100,0 \\
\hline
\end{tabular}

Araştırmaya katılanların kitle iletişim araçlarını kullanım sıklıklarını ve bu araçlardan televizyonun kullanım durumunu ortaya çlkarmaya yönelik olarak sorulan soru grubunun sonuçları Tablo-2'de incelendiğinde ortaya çıkan sonuçlar şu şekildedir; internet ve televizyon, ortalaması 3'ün üzerinde olan kitle iletişim araçları olarak ortaya çıkmıştır. $\mathrm{Bu}$ araçlardan katılımcıların en fazla kullandıkları araç internet olarak ortaya çıkmıştır $(4,65)$. İkinci sırada kitap okuma $(3,65)$ gelmektedir. Televizyon ise en sık kullanılan üçüncü araç olarak karşımıza çıkmaktadır $(3,05)$.

Tablo 2. Kitle İletişim Araçları Kullanım Ortalamaları

\begin{tabular}{|l|c|c|c|c|c|}
\hline & N & Min. & Maks. & Ortalama & SS. \\
\hline İnternet & 303 & 1,00 & 5,00 & 4,6568 & 0,71015 \\
\hline Gazete & 303 & 1,00 & 5,00 & 2,3894 & 1,02944 \\
\hline Radyo & 303 & 1,00 & 5,00 & 2,7954 & 1,10883 \\
\hline Televizyon & 303 & 1,00 & 5,00 & 3,0594 & 1,13191 \\
\hline Toplam & 303 & & & & \\
\hline
\end{tabular}

Araştırmaya katılanların televizyonu takip etme amaçları Tablo 3'te görülmektedir. Buna göre katılımcıların yarısına yakını olan \%47,5’i vakit geçirmek amaçlı takip ettiğini söylemektedir. Diğer taraftan \%19,1'i bilgi edinme, 12,9'u eğlenme, \%2,3'ü ise sosyalleşme amaçlı takip ettiğini söylemiştir. \%18,2'lik kesim ise televizyonu takip etmediğini belirtmiştir.

Tablo 3. Televizyonu Takip Etme Amacl

\begin{tabular}{|l|c|c|}
\hline & Frekans & Yüzde \\
\hline Bilgi edinme & 58 & 19,1 \\
\hline Sosyalleşme & 7 & 2,3 \\
\hline Vakit geçirme & 144 & 47,5 \\
\hline Eğlenme & 39 & 12,9 \\
\hline Takip etmiyorum & 55 & 18,2 \\
\hline Toplam & 303 & 100,0 \\
\hline
\end{tabular}

Katılımcıların dini bilgi edinmede kullandıkları kanallar (Tablo 4) incelendiğinde, dini bilgi edinme \%36,3 ile en fazla camide gerçekleşmektedir. Araştırma sonuçlarına göre okul da \%28,1 ile en fazla dini bilgi edinilen kanallardan birisi olarak karşımıza çıkmıştır. 
Ailede dini bilgi edinme oranı ise \%27,7 olarak ortaya çıkmıștır. Medyadan dini bilgi edindiğini söyleyenlerin oranı ise \%2,3 düzeyinde kalmıştır. $\mathrm{Bu}$ sonuçlar gençlerin dini bilgiyi edinmede medyayı tercih etmediğini göstermektedir. Diğer taraftan genç yetişkinler dini bilgi edinmeyi daha çok cami aracılığı ile yaptığı görülmektedir.

Tablo 4. Dini Bilgi Edinme Kanalları

\begin{tabular}{|l|c|c|}
\hline & Frekans & Yüzde \\
\hline Ailede & 84 & 27,7 \\
\hline Okulda & 85 & 28,1 \\
\hline Fikrim yok & 3 & 1,0 \\
\hline Camide & 110 & 36,3 \\
\hline Dini Eğitim Almadım & 7 & 2,3 \\
\hline Medya & 7 & 2,3 \\
\hline Cevapsız & 7 & 2,3 \\
\hline Toplam & 303 & 100,0 \\
\hline
\end{tabular}

Araştırmaya katılan katılımcıların televizyondaki dini programları izleme sıklıklarını (Tablo 5) incelediğimizde; \%59,4'ünün çeşitli düzeylerde bu tür programları izlemediği görülmektedir. Diğer taraftan çeşitli düzeylerde televizyondaki dini programları izleyenlerin oranı ise \%40,6 olarak ortaya çıkmıştır. Buna göre genç izleyicilerin çoğunluğunun televizyondaki dini programları seyretmediği sonucu ortaya çıkmaktadır.

Tablo 5. Televizyondaki Dini Programları İzleme Siklıkları

\begin{tabular}{|l|c|c|}
\hline & Frekans & Yüzde \\
\hline Sürekli İzlerim & 6 & 2,0 \\
\hline İzlerim & 80 & 26,4 \\
\hline Bazen İzlerim & 37 & 12,2 \\
\hline İzlemem & 94 & 31,0 \\
\hline Hiç İzlemem & 86 & 28,4 \\
\hline Toplam & 303 & 100,0 \\
\hline
\end{tabular}

Yapılan araştırmada ortaya çıkan ki kare testi sonucuna göre katılımcıların televizyondaki dini fetvalara güven düzeyi ile cinsiyetleri arasında anlamlı bir ilişki ortaya çıkmıştır $(\mathrm{p}=0,000)$. Tablo 6 incelendiğinde kadınların \%28,2'si kesinlikle güvenmiyorum, \%30,5'i güvenmiyorum, \%24,3'ü fikrim yok, \%13'ü güveniyorum ve $\% 4$ ise kesinlikle güveniyorum cevabını vermiştir. Erkeklerin ise \%36,5'i kesinlikle güvenmiyorum, \%7,1'i güvenmiyorum derken $\% 27,8$ ise fikrim yok demiștir. Güveniyorum diyenlerin oranı $\% 25,4$ iken kesinlikle güveniyorum diyenlerin oranı ise $\% 3,2$ olarak ortaya çıkmıştır.

Ortaya çıkan bu sonuçlara göre kadınların televizyondaki dini fetvalara güven düzeyleri ile ilgili olumsuz yanıt verenlerin oranı \%58,7 olarak ortaya çıkmaktadır. Erkeklerde ise bu oran \%52,5 olmuştur. Bu sonuçlara göre kadınların erkeklere oranla televizyondaki dini fetvalara güven düzeyinin daha az olduğu söylenebilir. 
Tablo 6. Cinsiyet ve Televizyondaki Dini Fetvalara Güven Düzeyi

\begin{tabular}{|c|c|c|c|c|c|c|}
\hline & \multicolumn{5}{|c|}{ Televizyondaki Dini Fetvalara Güven Düzeyi } & \multirow[b]{2}{*}{ Toplam } \\
\hline & \multirow{2}{*}{$\begin{array}{c}\begin{array}{c}\text { Kesinlikle } \\
\text { Güvenmiyorum }\end{array} \\
50\end{array}$} & \multirow{2}{*}{$\begin{array}{c}\text { Güvenmiyorum } \\
54\end{array}$} & \multirow{2}{*}{$\begin{array}{c}\text { Fikrim yok } \\
43\end{array}$} & Güveniyorum & \multirow{2}{*}{\begin{tabular}{|c|}
$\begin{array}{c}\text { Kesinlikle } \\
\text { Güveniyorum }\end{array}$ \\
7
\end{tabular}} & \\
\hline \multirow{4}{*}{ Kadın } & & & & 23 & & 177 \\
\hline & $28,2 \%$ & $30,5 \%$ & $24,3 \%$ & $13,0 \%$ & $4,0 \%$ & $100,0 \%$ \\
\hline & $52,1 \%$ & $85,7 \%$ & $55,1 \%$ & $41,8 \%$ & $63,6 \%$ & $58,4 \%$ \\
\hline & $16,5 \%$ & $17,8 \%$ & $14,2 \%$ & $7,6 \%$ & $2,3 \%$ & $58,4 \%$ \\
\hline \multirow{4}{*}{ Erkek } & 46 & 9 & 35 & 32 & 4 & 126 \\
\hline & $36,5 \%$ & $7,1 \%$ & $27,8 \%$ & $25,4 \%$ & $3,2 \%$ & $100,0 \%$ \\
\hline & $47,9 \%$ & $14,3 \%$ & $44,9 \%$ & $58,2 \%$ & $36,4 \%$ & $41,6 \%$ \\
\hline & $15,2 \%$ & $3,0 \%$ & $11,6 \%$ & $10,6 \%$ & $1,3 \%$ & $41,6 \%$ \\
\hline \multirow{4}{*}{ Toplam } & 96 & 63 & 78 & 55 & 11 & 303 \\
\hline & $31,7 \%$ & $20,8 \%$ & $25,7 \%$ & $18,2 \%$ & $3,6 \%$ & $100,0 \%$ \\
\hline & $100,0 \%$ & $100,0 \%$ & $100,0 \%$ & $100,0 \%$ & $100,0 \%$ & $100,0 \%$ \\
\hline & $31,7 \%$ & $20,8 \%$ & $25,7 \%$ & $18,2 \%$ & $3,6 \%$ & $100,0 \%$ \\
\hline
\end{tabular}

Tablo 7'de t-testi sonuçları görülmektedir. Katılımcıların cinsiyetleri itibariyle dini programlardaki kişilerin uzmanlık durumu arasında $(0,028)$, Televizyondaki dini programları izleme durumu arasında $(0,019)$, TV dini inançları değiştirmiştir ifadesinde $(0,008)$ ve TV dini inançları yaymada etkilidir $(0,013)$ ifadesinde anlamlı farklılıklar görülmektedir. Tablo 7'de ortaya çıkan sonuçlar incelendiğinde TV'de dini yayınlarda uzman olmayan kişilere yer verilmemelidir maddesine erkeklerin kadınlardan daha fazla katıldığını göstermektedir. Televizyondaki dini programları izleme durumuna baktığımızda, erkeklerin kadınlardan daha fazla televizyondaki dini programları izlediği görülmektedir. TV dini inançları değiştirmiştir maddesinde ise kadınların ortalamasının daha yüksek olduğu görülmektedir. Son olarak TV dini inançları yaymada etkilidir diyenlerde erkekler kadınlara göre daha fazla ortalamaya sahiptir.

Diğer taraftan araştırmamız kapsamında katılımcılara yöneltilen; TV'de dini konularla ilgili yayın yapılmamalı, TV dini reyting amaçlı istismar etmektedir, TV'deki dini fetvalara güvenirim, TV'deki dini yayınlar yeterlidir, TV'de çocuklara yönelik dini bilgilendirme yapılmalıdır, TV dini gündem oluşturabilir ve küreselleşen dünyada din önemini kaybetmiştir maddelerinde kadın ve erkek katılımcılar arasında anlamlı bir farklılaşma tespit edilmemiștir.

Tablo 7. T-Testi Sonuçları

\begin{tabular}{|c|c|c|c|c|c|c|c|}
\hline İfadeler & Değişken & N & $\bar{\square}$ & SS & t-value & SD & Sig. \\
\hline $\begin{array}{l}\text { TV'de dini yayınlarda uzman olmayan } \\
\text { kişilere yer verilmemelidir }\end{array}$ & $\begin{array}{l}\text { Kadın } \\
\text { Erkek }\end{array}$ & $\begin{array}{l}177 \\
126\end{array}$ & $\begin{array}{l}4,29 \\
4,55\end{array}$ & $\begin{array}{l}1,20 \\
0,81\end{array}$ & 2,202 & 301 & ,028 \\
\hline $\begin{array}{l}\text { Televizyondaki dini programları } \\
\text { izleme durumu }\end{array}$ & $\begin{array}{l}\text { Kadın } \\
\text { Erkek }\end{array}$ & $\begin{array}{l}177 \\
126\end{array}$ & $\begin{array}{l}3,44 \\
3,76\end{array}$ & $\begin{array}{l}1,28 \\
1,07\end{array}$ & 2,362 & 301 & ,019 \\
\hline TV dini inançları değiştirmiştir & $\begin{array}{l}\text { Kadın } \\
\text { Erkek }\end{array}$ & $\begin{array}{l}177 \\
126\end{array}$ & $\begin{array}{l}3,39 \\
3,01\end{array}$ & $\begin{array}{l}1,19 \\
1,24\end{array}$ & 2,661 & 301 & ,008 \\
\hline TV dini inançları yaymada etkilidir & $\begin{array}{l}\text { Kadın } \\
\text { Erkek }\end{array}$ & $\begin{array}{l}177 \\
126\end{array}$ & $\begin{array}{l}2,98 \\
3,32\end{array}$ & $\begin{array}{l}1,17 \\
1,13\end{array}$ & 2,503 & 301 & ,013 \\
\hline TV'de dini konularla ilgili yayın yapılmamalı & $\begin{array}{l}\text { Kadın } \\
\text { Erkek }\end{array}$ & $\begin{array}{l}177 \\
126 \\
\end{array}$ & $\begin{array}{l}2,82 \\
2,93 \\
\end{array}$ & $\begin{array}{l}1,39 \\
1,41 \\
\end{array}$ & ,652 & 301 &, 515 \\
\hline TV dini reyting amaçlı istismar etmektedir & $\begin{array}{l}\text { Kadın } \\
\text { Erkek }\end{array}$ & $\begin{array}{l}177 \\
126\end{array}$ & $\begin{array}{l}3,77 \\
3,49\end{array}$ & $\begin{array}{l}1,14 \\
1,42\end{array}$ & 1,874 & 301 & ,062 \\
\hline
\end{tabular}




\begin{tabular}{|c|c|c|c|c|c|c|c|}
\hline İfadeler & Değişken & $\mathbf{N}$ & $\overline{\mathrm{C}}$ & SS & t-value & SD & Sig. \\
\hline TV'deki dini fetvalara güvenirim & $\begin{array}{l}\text { Kadın } \\
\text { Erkek }\end{array}$ & $\begin{array}{l}177 \\
126\end{array}$ & $\begin{array}{l}2,33 \\
2,51\end{array}$ & $\begin{array}{l}1,13 \\
1,30\end{array}$ & 1,22 & 301 & ,220 \\
\hline TV'deki dini yayınlar yeterlidir & $\begin{array}{l}\text { Kadın } \\
\text { Erkek }\end{array}$ & $\begin{array}{l}177 \\
126 \\
\end{array}$ & $\begin{array}{l}2,39 \\
2,65\end{array}$ & $\begin{array}{l}1,22 \\
1,24 \\
\end{array}$ & 1,77 & 301 & ,078 \\
\hline $\begin{array}{l}\text { TV'de çocuklara yönelik dini } \\
\text { bilgilendirme yapılmalıdır }\end{array}$ & $\begin{array}{l}\text { Kadın } \\
\text { Erkek }\end{array}$ & $\begin{array}{l}177 \\
126 \\
\end{array}$ & $\begin{array}{l}3,40 \\
3,38 \\
\end{array}$ & $\begin{array}{l}1,27 \\
1,33 \\
\end{array}$ &, 132 & 301 & ,895 \\
\hline TV dini gündem oluşturabilir & $\begin{array}{l}\text { Kadın } \\
\text { Erkek }\end{array}$ & $\begin{array}{l}177 \\
126 \\
\end{array}$ & $\begin{array}{l}3,22 \\
3,35\end{array}$ & $\begin{array}{l}1,28 \\
1,29 \\
\end{array}$ & ,909 & 301 & ,364 \\
\hline $\begin{array}{l}\text { Küreselleşen dünyada din } \\
\text { önemini kaybetmiştir }\end{array}$ & $\begin{array}{l}\text { Kadın } \\
\text { Erkek }\end{array}$ & $\begin{array}{l}177 \\
126\end{array}$ & $\begin{array}{l}3,58 \\
3,59\end{array}$ & $\begin{array}{l}1,16 \\
1,32\end{array}$ & ,091 & 301 & ,928 \\
\hline
\end{tabular}

Araştırmamız kapsamında katılımcılardan televizyondaki dini programların eksik yönlerini yazmaları istenmiştir. Açık uçlu olarak yöneltilen bu soruya verilen cevapların frekans dağılımları Tablo 8'de görülmektedir. Verilen cevaplar konulara sınıflandırılarak 11 açıdan sunulmuştur. Ortaya çıkan sonuçlar incelendiğinde bu soruya yanıt veren 119 katılımcı olduğu görülmektedir. 119 katılımcının televizyondaki dini programının eksik yönleri ile ilgili düşüncelerine baktığımızda öne çıkan eksik yönler; televizyondaki dini programların reyting amacıyla hareket ettiği düşüncesi $(\% 7,6)$, dini açıdan yanlış bilgi verildiği düşüncesi $(\% 7,6)$, dini programların dini çarpıttıkları düşüncesi $(\% 4,6)$ ve dini programlara çıkan kişilerin bilgisiz ve yetersiz olmaları düşüncesi (\%4) dini programların eksik yönleri olarak öne çıkmaktadır.

Tablo 8. Katılımcıların Televizyondaki Dini Programların Eksik Yönü ile İlgili Düşünceleri

\begin{tabular}{|l|c|c|}
\hline & Sayı & Yüzde \\
\hline Geçerli & 119 & 39,2 \\
\hline Ayrışııııı olması & 3 & 1,0 \\
\hline Programa bilgisiz ve yetersiz kişilerin çıkması & 12 & 4,0 \\
\hline Dini çarpıtmaları & 14 & 4,6 \\
\hline Dini sömürü yapılması & 6 & 2,0 \\
\hline Gereksiz olması & 3 & 1,0 \\
\hline İlgi çekici olamaması & 6 & 2,0 \\
\hline Politik olması & 8 & 2,6 \\
\hline Reyting amaçlı olması & 23 & 7,6 \\
\hline Samimi olmaması & 14 & 4,6 \\
\hline Tarafsız olmaması & 7 & 2,3 \\
\hline Yanlış bilgi verilmesi & 23 & 7,6 \\
\hline Toplam & 303 & 100,0 \\
\hline
\end{tabular}

Araștırmamız kapsamında katılımcıların medyadaki dini programlara bakış açılarını ortaya çıkarmak amacıyla yöneltilen soru grubuna verilen cevapların betimleyici analiz sonuçları Tablo 9'da görülmektedir. Verilen cevaplar incelendiğinde ortaya şu sonuçlar çıkmaktadır:

Ortalamanın üstünde çıkan sonuçlar incelendiğinde en dikkat çekici sonuç “TV'de dini yayınlarda uzman olmayan kişilere yer verilmemelidir" ifadesine verilen cevaplarda ortaya çıkmıştır. Bu ifadenin ortalaması 4,4059 gibi yüksek bir ortalamaya sahiptir. Dikkat çekici bir diğer sonuç ise "TV dini reyting amaçlı istismar etmektedir" ifadesine verilen cevapların ortalamasıdır. Burada sonuç 3,6601 olarak ortaya çıkmaktadır. Ortalamanın üstünde çıkan diğer ifade ise "TV'de çocuklara yönelik dini bilgilendirme yapılmalıdır" ifadesidir. Bu ifadenin ortalaması 3,3927'dir. "Küreselleșen dünyada din önemini 
kaybetmiştir" ifadesine baktığımızda bu bakış açısının ortalaması 3,5875 olarak ortaya çıkmıştır. Araştırma sonuçlarına göre katılımcılar "TV'de dini gündem oluşturabilir" ifadesine yine ortalamanın üstünde olumlu yanıtlar vermişlerdir (3,2772). "TV dini inançları değiştirmiştir" ifadesinin ortalaması da yine üçün üzerinde olan ifadelerden birisidir ve 3,2376 olarak ortaya çıkmıştır. Son olarak "TV dini inançları yaymada etkilidir" ifadesi üçün üzerinde ortaya çıkan bir ifade olarak karşımıza çıkmaktadır. Bu ifadenin ortalaması ise 3,1287dir.

Diğer taraftan ortalaması üçün altında çıkan ifadelere baktığımızda, “TV'deki dini fetvalara güvenirim" yargısının ortalaması 2,4125 ile en düşük seviyedeki ifade olarak dikkat çekmektedir. "TV'deki dini yayınlar yeterlidir" ifadesi ise 2,5017 ortalama ile yine üçün altında kalmıştır. Son olarak "TV'de dini konularla ilgili yayın yapılmamalı" ifadesinin ortalaması 2,8713 olarak ortaya çıkmıştır.

Tablo 9. Dini Programlara Bakış Açıları

\begin{tabular}{|l|c|c|c|c|c|}
\hline & Sayı & Minimum & Maksimum & Ortalama & SS. \\
\hline TV'de dini konularla ilgili yayın yapılmamalı. & 303 & 1,00 & 5,00 & 2,8713 & 1,44431 \\
\hline TV dini reyting amaçlı istismar etmektedir. & 303 & 1,00 & 5,00 & 3,6601 & 1,27636 \\
\hline TV'deki dini fetvalara güvenirim. & 303 & 1,00 & 5,00 & 2,4125 & 1,20901 \\
\hline TV'deki dini yayınlar yeterlidir. & 303 & 1,00 & 5,00 & 2,5017 & 1,23652 \\
\hline $\begin{array}{l}\text { TV'de dini yayınlarda uzman olmayan } \\
\text { kişilere yer verilmemelidir. }\end{array}$ & 303 & 1,00 & 5,00 & 4,4059 & 1,06893 \\
\hline $\begin{array}{l}\text { TV'de çocuklara yönelik dini } \\
\text { bilgilendirme yapılmalıdır. }\end{array}$ & 303 & 1,00 & 5,00 & 3,3927 & 1,29730 \\
\hline TV dini gündem oluşturabilir. & 303 & 1,00 & 5,00 & 3,2772 & 1,28763 \\
\hline Küreselleşen dünyada din önemini kaybetmiştir. & 303 & 1,00 & 5,00 & 3,5875 & 1,23072 \\
\hline TV dini inançları değiştirmiştir. & 303 & 1,00 & 5,00 & 3,2376 & 1,22730 \\
\hline TV dini inançları yaymada etkilidir. & 303 & 1,00 & 5,00 & 3,1287 & 1,17081 \\
\hline Geçerli Toplam & 303 & & & & \\
\hline
\end{tabular}

\section{Sonuç}

Televizyon, günümüzde insanların yaşamlarını etkileyen en önemli kitle iletişim araçlarından birisidir. Bu etkiden payını alan gruplardan birisi de gençlerdir. Diğer bireyler gibi gençler de televizyonu birçok amaçla kullanmaktadırlar. Bilgi edinme, boş vakit geçirme, sosyalleşme, eğlenme başlıca kullanım sebepleri olarak karşımıza çıkmaktadır. $\mathrm{Bu}$ amaçlardan özellikle bilgi edinmede televizyonun rolü yadsınamaz. Zira televizyonda belgeselden ekonomiye, haberlerden tartışma programlarına kadar birçok içerik bireylerin bilgi edinmelerine katkı sunar. Bu programlardan birisi de dini programlardır. Bilindiği gibi dini programlar gerek içeriği gerekse de takipçi kitlesi bakımından farklılık gösterebilmektedir. Birçok işleve sahip olan dini programların içerik bakımından sahip olduğu işlevlerden birisi de bilgi edinmedir. Zira insanların dini bilgi edinmelerinde dini programlar önemli bir yere sahiptir. Ancak bu programlardaki dini bilgilerin güvenilir olup olmadığı sorusu bu noktada araștırılması gereken bir konudur. Bir diğer konuysa insanların bu programlara güvenip güvenmediği ve bu programlara yönelik tutumlarının ne olduğudur. Bu bağlamda "gençlerin televizyondaki dini programlara yönelik tutumları ve güven düzeyleri nedir?" sorusundan yola çıkarak yaptığımız araştırma sonuçları şu şekilde ortaya çıkmıştır: Araştırma sonuçlarına göre gençler televizyondaki dini programlarda uzman olmayan kişilere yer verilmemesi gerektiğini düşünmektedirler. Bu düşünce erkeklerde kadınlara göre daha fazla öne çıkmaktadır. Dolayısıyla televizyondaki dini içerikli programlarda yer alan kişilerin alanlarında uzman olmaları önemsenen 
bir durumdur. Genç yetişkinler, televizyondaki dini programların reyting amaçlı olarak dini yönden istismar edildiğini düşünmektedirler. Özellikle kutsal gün ve gecelerde televizyon kanallarında yer alan dini programların sayısının artışının bu görüşün ortaya çıkmasına zemin hazırladığı savunulabilir. Yine genç yetişkinler, televizyonda çocuklara yönelik olarak dini bilgilendirme yapılması gerektiğini düşünmektedirler. Ancak bu sonucu dini programlarda uzman kişilere yer verilmesi gerekliliği sonucu ile birlikte düşünmek gerektiği de unutulmamalıdır. Öne çıkan bir diğer önemli sonuca göre ise gençler, televizyonda dini gündem oluşturulabileceğini düşünmektedirler. Bu sonucun televizyon aracının gündem oluşturmadaki gücü ile doğru orantılı olduğu şüphesizdir. Ortaya çlkan diğer önemli sonuçlara göre ise genç yetişkinlerde, televizyondaki dini programlara kadınların erkeklere göre daha az güvendiği, genç yetişkinlerin küreselleşme ile beraber dinin önemini kaybettiğini düşünmeleri ve televizyonun dini inançları değiştirdiğini düşünmeleridir.

Özellikle son yıllarda konuyla ilgili yapılan çalışma sayısında artış bulunmasına rağmen özellikle yerli literatürde yeterli çalışma olmadığı söylenebilir. Bundan sonraki konuyla ilgili daha büyük örneklem üzerinde yapılacak çalışmalar literatüre katkı sağlayacaktır. Ayrıca çalışmamızda gençler üzerine odaklanılmıştır. İleride yapılacak olan yetişkinlere yönelik çalışmaların yanında, daha büyük bir örneklem ile yapılacak çalışmalar da konunun daha iyi anlaşılmasına katkı sağlayacaktır.

\section{Çalışmanın Etik İzin Bilgileri}

Erciyes Üniversitesi Sosyal ve Beşeri Bilimler Etik Kurulu 28/08/2020 tarih ve 136 başvuru no'lu kararı çerçevesinde çalışma etik açıdan bir sakınca içermemektedir.

\section{Kaynakça}

Arslan, M. (2016). Kitle iletişim araçları, medya ve din ilişkisi üzerine. Birey ve Toplum Sosyal Bilimler Dergisi, 6(1), 5-26.

Diyanet İşleri Başkanlığı, (2014). Türkiye'de dini hayat araştırması. Ankara: Diyanet İşleri Başkanlığı Yayınları.

Bilis, A. (2017). Modern yaşamda dini değerlerin televizyonda temsili: "Nihat Hatipoğlu ile İftar" programı örneği. Selçuk İletişim, 9(4), 189-210.

Çelikkaya, M. F. (2010). Seküler bir kutsal oluşturma aracı olarak medya ve din ilișkisi, (Yayınlanmamış yüksek lisans tezi). Selçuk Üniversitesi Sosyal Bilimler Enstitüsü.

Dufek, J. J. (1992). The relationship between religious television and local church attendance (Order No. 9239711). Available from ProQuest Dissertations \& Theses Global. (304005529).

Eken, M. (2020). Modern görsel kültürde m nesli'nin online inanç pratikleri. Bilimname, 2020 (43), 31-71. DOI: 10.28949/bilimname.762744

Engstrom, E., \& Valenzano, J. M. (2014). Television, religion, and supernatural: Hunting monsters, finding gods. Maryland: Lexington Books.

Fiske, J. (2003). İletişim çalışmalarına giriş (2. Baskı b.). (S. İrvan, Çev.) Ankara: Bilim ve Sanat Yayınları.

Frederick, M. F. (2015). Colored television: American religion gone global. California: Stanford Universty Press. 
Furay, A. (2008). Yetişkinlerin yaygın din eğitiminde televizyonun yeri ve fonksiyonları (İstanbul Örneği)-Sır dizileri ve dini programlar, (Yayınlanmamış doktora tezi). İstanbul: İstanbul Üniversitesi Sosyal Bilimler Enstitüsü.

Gelici, Z. (2007). Sırlara vurgu yapan mistik televizyon programlarının din eğitimi açısından tahlili, (Yayınlanmamış yüksek lisans tezi). Sakarya : Sakarya Üniversitesi Sosyal Bilimler Enstitüsü.

Gerbner, G. (2017). Television: The new state religion? Etc: a review of general semantics, 74(3/4), 314-319.

Gülerarslan, A. (2010). Uhreviye karşi seküler: Din ve televizyon. Selçuk Üniversitesi Sosyal Bilimler Enstitüsü Dergisi(24), 222-228.

Güneş, A. (2018). Medyanın olumsuz din algısına etkisi. Fırat Üniversitesi Sosyal Bilimler Dergisi, 28(1), 203-216.

Kazi, T. (2018). Religious television and contesting piety in Karachi, Pakistan. American Anthropologist, 120(3), 523-534.

Martin, W. (2007). Seeking through the small screen: Television as a resource for negotiating and constructing personal spirituality (Order No. NR49379). Available from ProQuest Dissertations \& Theses Global. (304737517).

Postman, N. (2010). Televizyon öldüren eğlence: Gösteri çağında kamusal söylem. (0. Akınhay, Çev.) İstanbul: Ayrıntı Yayınları.

Rosengren, K. E. (1974). Uses and gratifications: A paradigm outlined. E. Katz, \& J. Blumler içinde, The uses of mass communications: current perspectives on gratifications research (s. 269-286). Bverly Hills CA: Sage.

Tanrıverdi, A. T. (2016). Televizyonlarda yayınlanan dini programların üniversite öğrencilerinin dini tutum ve davranışları ile ilişkisi: Adana Örneği, (Yayınlanmamış yüksek lisans tezi). Adana: Çukurova Üniversitesi Sosyal Bilimler Enstitüsü.

Thomas, S. P., \& Mitchell, J. p. (2005). Understanding television and Christianity in Marthoma Homes, South India. Studies in World Christianity, 11(1), 29-48.

Tolz, V. (2017). From a threatening "Muslim Migrant" back to the conspiring "West:" race, religion, and nationhood on Russian television during Putin's third presidency. Nationalities Papers, 45(5), 742-757.

Turan, İ. (2005). Dini içerikli televizyon programlarının yetişkinler üzerine etkisi / The effects of television program containing religious issues on adults, (Yayınlanmamış yüksek lisans tezi). Samsun: Ondokuz Mayıs Üniversitesi Sosyal Bilimler Enstitüsü.

Yenen, İ. (2005). Televizyonlarda yayınlanan dini programların izlerkitlenin dini tutum ve davranışları üzerine etkileri -Konya örneği-. Kayseri: Erciyes Üniversitesi Sosyal Bilimler Enstitüsü. 


\title{
Determining Young Adults' Attitudes and Confidence Levels towards Religious Programs on Television: An Empirical Study
}

\author{
İsmailcan Doğan (Asst. Prof. Dr.)
}

\section{Extended Abstract}

Along with the industrial revolution, there have been dizzying developments in the field of communication, as in many areas. One of these developments is undoubtedly developments in the field of mass communication. Mass media that affect people's lifestyles have an important place in this sense. Television, one of these tools, has also been one of the most important actors of the change in society and individuals in this context. Television broadcasting, which began in the 20th century, differed from other mass media and came to the fore with its feature of transmitting images and sound simultaneously and live. The fact that television has many features and that it can deliver both the image and sound to the masses at the same time has been one of the leading reasons for television to be preferred by the audience from the past to the present. This study aims to reveal the perspectives and viewing habits of young viewers of religious programs on television: Why they watch them, their level of trust in these programs, their motivation to watch. In this context, our study consists of literature and research sections. In the literature section, first of all, the subject between television and religion was briefly mentioned, and the situation of the subject in social sciences was addressed. In the research section, a field study and results on the subject are presented.

As part of our study, a survey form has been created for our field research. The survey form was completed through face-to-face interview method in the Central Districts of Kayseri province in December 2019. The created survey form consists of three parts. In the first part, questions about the frequency of using mass media were asked, in the second part, questions were asked to reveal the attitudes and behaviors about religious programs in the media, and in the last part, questions were asked to determine the sociodemographic characteristics of the participants. A 5-point Likert scale type was used in the questions of the study. The questions to reveal the frequency of the participants using mass media had the choices as 1: Never, 2: Rarely, 3: Sometimes, 4: Often, 5: Always. Then, in the question group asked to reveal the attitudes and confidence levels of the participants towards religious programs on television, they were asked to select one of the choices from 1: Strongly disagree, 2: Disagree, 3: Neither agree nor disagree, 4: Agree, 5: Strongly agree. In the last part, questions were asked about the socio-demographic characteristics of the participants.

The level of trust in television and religious programs was limited, focusing on young people between the ages of 18 and 30 only. The sample of the study was randomly selected from young people aged 18-30 living in the center of Kayseri province. Given the population of Kayseri, 303 people were surveyed face-to-face with a trust level of $90 \%$. Analysis of the data was carried out in the SPSS 22 statistical package program. In our study, analyses such as frequency, average, chi-square, median, lowest and highest value were used and the results were interpreted in the table.

Our study is of young adults. In this context, individuals in the 18-30 age range constitute the main limitation of our study. Besides, our study was conducted in the central districts 
of Kayseri province, as reaching the entire universe is difficult in terms of cost and time. On the other hand, the data collection of the study is limited to the survey method, which is one of the data collection tools.

According to the results of the study, young adults think that non-experts should not be allowed to participate in religious programs on television. Apart from that, it was found that female trusts religious programs on television less than male. It also seems that young adults do not follow religious content programs on television much. According to young adults, this is due to some religious programs' abuse of religion. In other words, young people think that the main purpose of religious television programs is ratings. However, young people also support religious information for children on television. Another result of our study is that young people think that religion has lost its importance with globalization. It is also seen that young people think that television changes religious beliefs. Another important result that stands out is that young people think that a religious agenda can be created on television.

Keywords: Media, Television, Religion, Media and Religion, Television Programs.

Bu makale intihal tespit yazılımlarıyla taranmıştır. İntihal tespit edilmemiş̧ir.

This article has been scanned by plagiarism detection softwares. No plagiarism detected.

Bu çalışmada "Yükseköğretim Kurumları Bilimsel Araştırma ve Yayın Etiği Yönergesi” kapsamında uyulması belirtilen kurallara uyulmuştur.

In this study, the rules stated in the "Higher Education Institutions Scientific Research and Publication Ethics Directive" were followed. 